\title{
The Role of Cognitive Skills, Non-Cognitive Skills, and Internet Use on Entrepreneurs' Success in Indonesia
}

\author{
Lia Gustina ${ }^{1}$, Diah Ayu Utami ${ }^{2}$, Padang Wicaksono ${ }^{3^{*}}$ \\ 1,2,3 Universitas Indonesia, Indonesia, \\ 1liagst1986@gmail.com, 2diahayuutami86@gmail.com, ${ }^{3}$ padangwicaksono@gmail.com, *corresponding author
}

\begin{abstract}
This study aims to analyze the effect of cognitive skills, non-cognitive skills, and internet use on the entrepreneur's success in Indonesia. Using the Indonesian Family Life Survey (IFLS) conducted in 2014 (IFLS-5), this study observed people of 15-64 years old who work as entrepreneurs which amounted to 4.111 observations. The model used is Ordinary Least Square (OLS) Regression. The results showed that cognitive and non-cognitive skills will determine the entrepreneur's success by profit measure. The higher the cognitive and non-cognitive skills possessed by the entrepreneur, the higher the profit obtained. Entrepreneurs who use the internet will also get higher profits than entrepreneurs who do not use the internet. In addition, the profit earned by the entrepreneur will be even higher if: age increases, of male sex, is highly educated and is living in urban areas.
\end{abstract}

Keywords: entrepreneur, cognitive skills, non-cognitive skills, internet, OLS

\section{Peran Kemampuan Kognitif dan Nonkognitif serta Penggunaan Internet terhadap Kesuksesan Wirausaha di Indonesia}

\begin{abstract}
Abstrak
Penelitian ini bertujuan untuk mengetahui peranan variabel kemampuan kognitif, kemampuan nonkognitif, dan penggunaan internet terhadap kesuksesan seorang wirausaha. Data yang digunakan bersumber dari Indonesian Family Life Survey (IFLS) tahun 2014 (IFLS-5) dan unit analisisnya adalah individu usia 15-64 tahun yang bekerja sebagai wirausaha dengan observasi berjumlah 4.111 individu. Metode yang digunakan adalah Ordinary Least Square (OLS) Regression. Hasil penelitian menunjukkan bahwa kemampuan kognitif dan nonkognitif akan menentukan kesuksesan wirausaha yang diukur dengan profit yang diperoleh. Semakin tinggi kemampuan kognitif dan nonkognitif yang dimiliki wirausaha menunjukkan profit yang diperoleh semakin tinggi. Wirausaha yang menggunakan internet juga akan memperoleh profit yang lebih tinggi dibanding wirausaha yang tidak menggunakan internet. Selain itu, profit yang diperoleh wirausaha akan semakin tinggi jika: usia semakin bertambah, berjenis kelamin laki-laki, berpendidikan tinggi (SMA ke atas), dan tinggal di daerah perkotaan.
\end{abstract}

Kata kunci: wirausaha, kemampuan kognitif, kemampuan nonkognitif, internet, OLS

\section{INTRODUCTION}

Based on population issues that occur in Indonesia, from 2020 to 2040, there will be a period called the windows of opportunity. The windows of opportunity is a condition that describes the number of productive age population (15-64 years old) that is greater than the number of unproductive age population (0-14 years old and 65 years old and above). The number of people of productive age will increase productivity which can trigger economic growth. However, economic growth will not automatically increase because it depends on many factors, especially the quality of labor (Adioetomo \& Pardede, 2018).

On the other hand, the increasing number of productive age population can also cause increased unemployment if it is not matched by the availability of employment Ilegbinosa et al., (2014). One of the solutions as well as included in one of the target RPJMN (National Medium-Term Development Plan) 2015-2019, is increasing the 
number of entrepreneurs in Indonesia (Bappenas, 2014). The important role of entrepreneurship is to reduce the level of unemployment because individual entrepreneurship can create employment for themselves or others (Georgellis \& Wall, 2004).

Based on data from the National Labor Force Survey (SAKERNAS) from 19862019 (BPS, 2019), the percentage of the number of entrepreneurs in Indonesia ranges from 36 to 48 percent of the total workforce employed in Indonesia. This figure illustrates the tendency of the labor force in Indonesia to work in other fields (besides entrepreneurship) that is still higher than working as an entrepreneur. If seen from the side of the development of the number of entrepreneurs, in the last decade, the number of entrepreneurs in Indonesia tends to decrease compared to the previous decade.

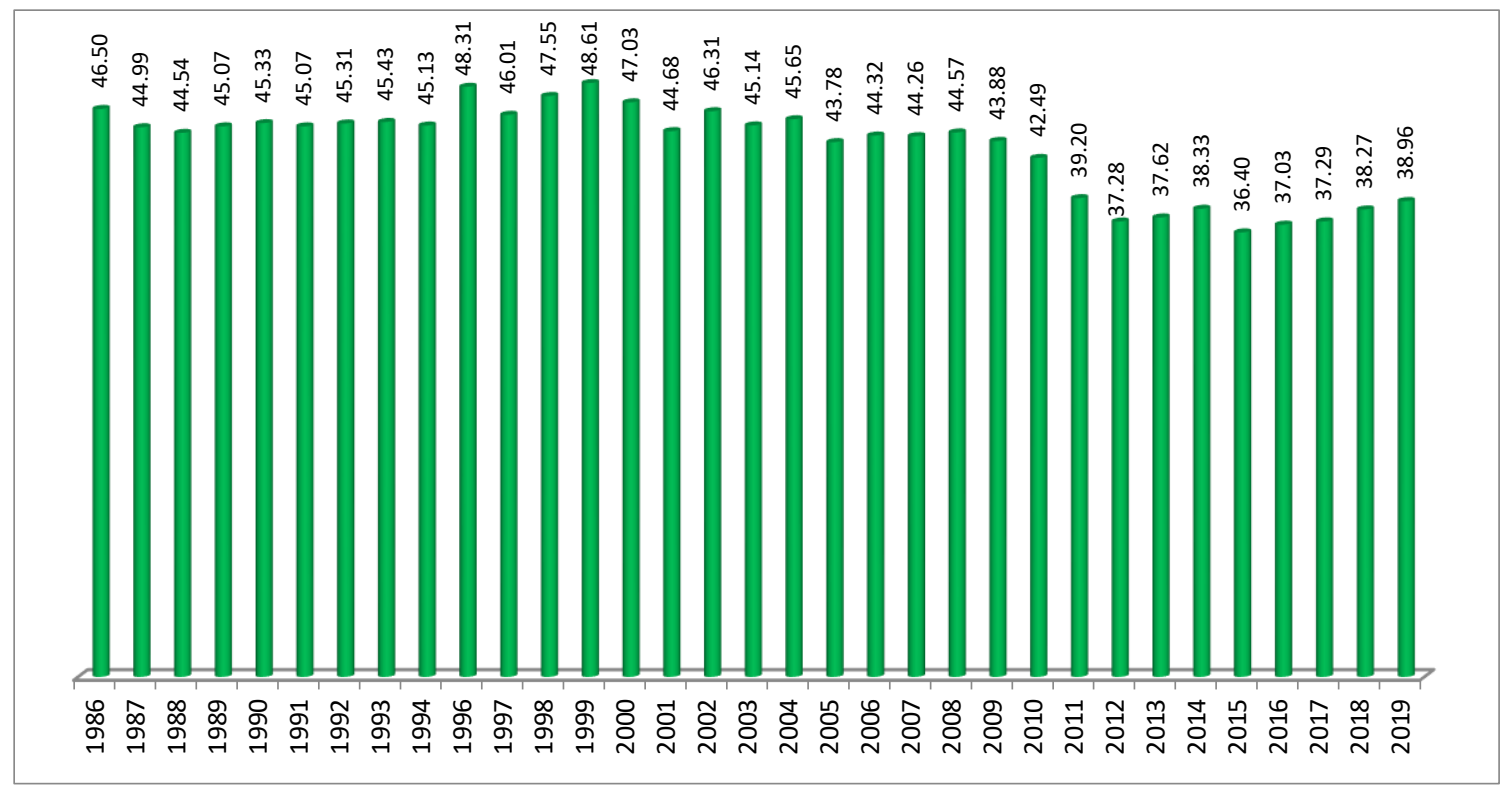

Source: BPS (2019), has been processed

Figure 1. Percentage of Entrepreneurs in Indonesia, 1986-2019

In 2019, the percentage of entrepreneurs in Indonesia based on the number of workers owned is still dominated by self-employment or self-employment with unpaid workers which is around 90,76 percent of total entrepreneurs (BPS, 2019). Entrepreneurs who have paid a minimum of one employee are still under ten percent even though from year to year they tend to show an increase but not too significant. It's showed that entrepreneurs in Indonesia are still dominated by small entrepreneurs or underdeveloped entrepreneurs (Kusumawardhani et al., 2019). In addition, the number of paid workers the entrepreneur has can illustrate the success of the entrepreneur in running his business (Mel et al., 2008; Djankov et al., 2005). Entrepreneurs' success can also be described from the profit earned or by the duration of business undertaken able to survive (Calderon et al., 2016; Marshall, 1890; Praag, 1997).

One of the factors that influence entrepreneurs' success is its human capital such as cognitive and non-cognitive skills (Meisenberg, 2012; Rauch et al., 2007; Hartog et al., 2010; Aldén et al., 2017; Heckman \& Kautz, 2012). The taxonomic theory by Bloom (1956) which has been revised by Anderson \& Krathwohl (2001) states that cognitive skills 
is one type of human thinking skills related to reason. The non-cognitive skills is skills related to emotional or attitudes that is in accordance with the norms or values of society.

According to Meisenberg (2012), individuals with cognitive skills higher than average are able to start and run their businesses more effectively and will be better able to innovate continuously in running their businesses. This is supported by the theory of Marshall (1890) which states that high cognitive skills possessed by an entrepreneur can encourage the entrepreneur to manage his business optimally so that the profits obtained will be even greater. In addition, according to Rauch et al., (2007), the cognitive skills of an entrepreneur will influence the entrepreneur in every decision making and action in running his business so that it will ultimately affect the success of the entrepreneur.

Hartog et al., (2010) also tried to do a research using a longitudinal sample of individuals in the age group of 15 to 23 years to see the relationship between skills and income earned by entrepreneurs without the help of paid or unpaid workers. Furthermore, Aldén et al., (2017) followed the method used by Hartog et al., (2010) but it was carried out in individuals aged 18-19 years. The results of both studies indicate a positive relationship between cognitive skills and income earned by entrepreneurs.

Some research also shows that non-cognitive skills and income have strong relationships as well as cognitive skills (Mueller \& Plug, 2004; Cobb-clark \& Schurer, 2011; Aldén et al., 2017; Hartog et al., 2010). According to Cubel et al., (2016), noncognitive skills or individual characters are a combination of emotional characteristics, attitudes, and behaviors that are specific to each individual. Suitability between characters, attitudes, and behavior of individuals and types of work will contribute to productivity at work. Therefore, economists have tried to develop workers' skills into cognitive and noncognitive skills (Adhitya et al., 2019).

Technological developments also play an important role in entrepreneurs' success. According to Das et al., (2018) the internet has brought a change for the better, especially for MSMEs ( Micro, Small and Medium Enterprises). The study of the use of the internet on entrepreneurs' performance was also carried out by Halab1 \& Lussier (2014) in Chile against 158 failed businesses, 101 moderate businesses, and 144 successful businesses. The results of his research show that businesses that use the internet are more successful businesses than do not use the internet. In addition, according to Kietzmann et al., (2011), the use of the internet and other information technologies such as the use of mobile phones, computers or laptops in developing countries has shown a positive influence on development because these facilities can support many business activities such as sharing information, building relationships, and communities. The study results of Li et al., (2019) in China in small businesses also found that the use of social media in business affects the success of male entrepreneurs but does not affect women entrepreneurs. This is because women entrepreneurs generally cannot take advantage of the information contained on social media.

This phenomenon regarding the skills of individuals and the use of the internet is trying to be captured in the IFLS (Indonesian Family Life Survey) conducted in 2014. It is interesting to analyze further if it is focused on entrepreneurship because most of the 
entrepreneurs in Indonesia are still in the form of micro-businesses and underdeveloped. Previous studies on entrepreneurs' success in Indonesia (Vial \& Hanoteau, 2015; Kusumawardhani et al., 2019) have not considered non-cognitive skills and internet usage so that this research is expected to be able to complete studies on entrepreneurship in Indonesia. Therefore, this study has several objectives to address the issues including whether cognitive skills, non-cognitive skills, and internet usage will increase an entrepreneur's success as measured by the profits obtained.

\section{METHOD}

This study uses data from the Indonesian Family Life Survey (IFLS) or the Indonesian Household Life Aspect Survey (SAKERTI) conducted in 2014 (IFLS-5). IFLS-5 data collection was carried out at the end of 2014 and early 2015. IFLS is the only long-term panel survey collected by RAND Corporation and in collaboration with educational institutions namely the University of Indonesia (UI) and Gajah Mada University (UGM). IFLS data collects data from individual respondents, households, communities, residences, educational facilities, and health facilities.

The unit of analysis in this study is individuals aged 15-64 years old who work as entrepreneurs. The number of units of analysis in this study is 4.111 individuals. The dependent variable in this study is entrepreneurs' success as measured by the amount of profit earned in one year, which is expressed by a numerical measurement scale. The independent variables for cognitive skills are formed from questions in the cognitive capacity section and in the EK2 book on IFLS-5. In the cognitive capacity section, there are a number of tests consisting of arithmetic, numerical progression, and mathematics. Whereas in the EK2 book, the assessment of cognitive skills uses the Raven's Progressive Colored Matrices (RPM) method, which is answering according to the pattern question to measure the development of logic. Cognitive skills scores are calculated as a percentage of correct answers.

For the aspect of non-cognitive skills, it can be seen in the personality section that is intended for individuals aged 15 years old or older at IFLS-5. Questions on personality aspects consist of 15 statements to ask respondents for approval or disapproval of themselves, namely: talkative, do the job perfectly, have new ideas/originality, spontaneous in expressing opinions, can deal pressure well, forgiving, not worrying too much, imaginative, tend not to be lazy, artistic, caring, work efficiently, can be sociable, not rude, and not easily nervous. Each question has the highest score of 5 and the lowest of 1 , so the maximum score of the 15 questions is 75 and the minimum score is 15 . In the same way, as the cognitive skills scores, non-cognitive skills assessments are calculated as the percentage of respondents' answers to total question score personality. Internet use variables are categorized into two, namely yes (using) and not (not using).

Other independent variables used in this study are age (numerical), gender (male or female), education (high, middle, low), and region (urban or rural). The formation of variables and operational definitions in this study can be seen in Table 1. 
Table 1. Variable Formation and Operational Definitions

\begin{tabular}{|c|c|c|c|c|}
\hline No & Variables & Question Sources & Measuring Result & Measuring Scale \\
\hline 1 & $\begin{array}{l}\text { Entrepreneurs' } \\
\text { Success } \\
\text { (LNPRFT) }\end{array}$ & $\begin{array}{l}\text { Book 3A Section } \\
\text { TK question TK } \\
26 \mathrm{~A} 3\end{array}$ & $\begin{array}{l}\text { The amount of profit earned in one } \\
\text { year }\end{array}$ & Numeric \\
\hline 2 & $\begin{array}{l}\text { Cognitive } \\
\text { Skills (COG) }\end{array}$ & $\begin{array}{l}\text { Book 3B Section } \\
\text { COB dan Book } \\
\text { EK2 }\end{array}$ & Cognitive Skills Score & Numeric \\
\hline 3 & $\begin{array}{l}\text { Non-cognitive } \\
\text { Skills } \\
\text { (NONCOG) }\end{array}$ & $\begin{array}{l}\text { Book 3B Section } \\
\text { PSN }\end{array}$ & Non-cognitive Skills Score & Numeric \\
\hline 4 & $\begin{array}{l}\text { Internet Use } \\
\text { (ITN) }\end{array}$ & $\begin{array}{l}\text { Book 3A Section } \\
\text { DL }\end{array}$ & $\begin{array}{l}1=\text { Yes } \\
0=\text { No (reference) }\end{array}$ & Categorical \\
\hline 5 & $\begin{array}{l}\text { Age } \\
(\mathrm{AGE})\end{array}$ & $\begin{array}{l}\text { Book 3A question } \\
\text { COV3 }\end{array}$ & Age at the last birthday & Numeric \\
\hline 6 & $\begin{array}{l}\text { Gender } \\
\text { (SEX) }\end{array}$ & $\begin{array}{l}\text { Book 3A question } \\
\text { COV5 }\end{array}$ & $\begin{array}{l}1=\text { Male } \\
0=\text { Female (reference) }\end{array}$ & Categorical \\
\hline 7 & $\begin{array}{l}\text { Education } \\
\text { (EDUC) }\end{array}$ & $\begin{array}{l}\text { Book 3A Section } \\
\text { DL }\end{array}$ & $\begin{array}{l}2=\text { High }(\mathrm{D} 1-\mathrm{S} 3) \\
1=\text { Middle }(\mathrm{SMA} / \mathrm{SMK}) \\
0=\text { Low }(<=\mathrm{SMP})(\text { reference })\end{array}$ & Ordinal \\
\hline 8 & $\begin{array}{r}\text { Region } \\
\text { (REG) }\end{array}$ & $\begin{array}{l}\text { Book K Section } \\
\text { SC }\end{array}$ & $\begin{array}{l}1=\text { Urban } \\
0=\text { Rural (reference) }\end{array}$ & Categorical \\
\hline
\end{tabular}

The analytical method used to answer this study consists of two methods, descriptive and inferential. Both of these methods are used to complement the existing picture of the factors influencing the entrepreneurs' success in Indonesia. The inferencing analysis used is OLS (Ordinary Least Square) Regression. The OLS function that will be used in this study is as follows:

$$
\begin{aligned}
\operatorname{Ln} P R F T= & \beta_{0}++\beta_{1} C O G+\beta_{2} N O N C O G+\beta_{3} I T N+\beta_{4} A G E+\beta_{5} S E X+\beta_{61} E D U C_{1}+ \\
& \beta_{62} E D U C++\beta_{7} R E G+\varepsilon
\end{aligned}
$$

Where $L n$ PRFT is the natural profit logarithm obtained for a year and $\varepsilon$ is the error that allegedly has an impact on earnings, but its value can not be observed in this study.

\section{Check Regression Model Assumptions}

In estimating OLS regression models, a good estimator must have the nature of BLUE (Best Linear Unbias Estimator) so that the model must meet several assumptions, namely:

\section{Multicollinearity}

Regression coefficients are usually interpreted as the size of the dependent variable if one independent variable rises or falls by one unit and all other independent variables are considered to be fixed. However, this interpretation is incorrect if there is a linear relationship between the independent variables. Multicollinearity is a linear relationship between regressors (independent variables). The way to detect multicollinearity is to use the Variance Inflation Factor (VIF). If the VIF value is smaller than 10.00 then it means that there is no multicollinearity of the data tested. Conversely, if the VIF value is greater than or equal to 10 , it indicates that there is multicollinearity in the tested data. 


\section{Heteroscedasticity}

Heteroscedasticity is an error variance that is not constant or forms a pattern. The way to check can be done by the scatter plot method between fitted value and residual. If the plot spreads immediately above and below the zero axes and does not form a particular pattern then it is stated that there are no symptoms of heteroscedasticity. Heteroscedasticity causes estimators of OLS regression to have no minimum variants, but OLS regression estimators remain linear and unbias.

\section{Check Regression Equation Modeling}

The steps in checking the regression model equation are:

\section{Test Multiple Regression Models ( Global Test)}

The Global Test basically tests whether all independent variables have a zero regression coefficient. In Equation 1 for example, the Global Test tests cognitive skills along with other independent variables which are effective for estimating profit.

$H_{0}: \beta_{1}=\beta_{2}=\beta_{3}=\cdots=\beta_{k}=0$

$H_{1}$ : At least there is one $\beta_{j} \neq 0$;

If $H_{0}$ is not rejected then this implies that all regression coefficients are zero and all independent variables do not provide benefits in estimating the value of the dependent variable (profit). If that happens, then it must use other independent variables or use a different model approach to estimate profit.

\section{Evaluate the Individual Regression Coefficients}

The next test is to test the regression coefficients of each independent variable one by one. The hypothesis used is

$H_{0}: \beta_{j}=0$

$H_{1}: \beta_{j} \neq 0$;

With t-statistics as follows

$t=\frac{b_{i}-0}{s_{b i}}$

Value $b_{i}$ refers to one of the regression coefficients and $s_{b i}$ refers to the standard deviation of the regression coefficient distribution. The decision is taken by looking at the $p$-value produced, where if the p-value is smaller than the level of significance that we want then the decision is rejected. Which means that the independent variable that we test is useful in explaining variations on the dependent variable.

\section{The Coefficient of Determination $\left(\mathbf{R}^{2}\right)$}

The coefficient of determination describes how much variation of the dependent variable can be explained by the independent variable. The value of $\mathrm{R}^{2}$ that is getting closer to 0 means that the variation of the dependent variable can not be explained by the independent variable at all. If $\mathrm{R}^{2}=1$, it means the variation of the dependent variable is fully explained by the independent variable. 
Jurnal Economia, 16(1), April 2020, 130-142

\section{FINDING AND DISCUSSION}

Table 2. Distribution of Sample Characteristics

\begin{tabular}{|c|c|c|c|}
\hline \multirow{2}{*}{ Caracteristics } & \multicolumn{3}{|c|}{ Descriptive } \\
\hline & Average & Minimum & Maximum \\
\hline Age & 42,36 & 15 & 64 \\
\hline \multicolumn{4}{|l|}{ Gender } \\
\hline Male & 54,90 & - & - \\
\hline Female & 45,10 & - & - \\
\hline \multicolumn{4}{|l|}{ Education } \\
\hline Low $(\leq \mathrm{SMP})$ & 70,23 & - & - \\
\hline Middle (SMA/SMK) & 24,18 & - & - \\
\hline High (D1-S3) & 5,59 & - & - \\
\hline \multicolumn{4}{|l|}{ Region } \\
\hline Living in Urban Area & 52,03 & - & - \\
\hline Living in Rural Area & 47,97 & - & - \\
\hline Cognitive Skills & 18,34 & 0 & 51,85 \\
\hline Non-cognitive Skills & 55,36 & 32 & 72 \\
\hline \multicolumn{4}{|l|}{ Internet Use } \\
\hline Yes & 18,29 & - & - \\
\hline No & 81,71 & - & - \\
\hline
\end{tabular}

Source: IFLS-5, processed by the author

According to the results of IFLS-5 in Table 2, the average age of entrepreneurs in this study was 42,36 years old and with the most being male (54,90 percent). Education successfully attained by entrepreneurs is mostly low education graduates, which amounted to 70,23 percent followed by 24,18 percent middle education graduates. In addition, a large part of entrepreneurs lives in urban areas (52,03 percent).

The skills of entrepreneurs in this study were seen from two aspects, namely cognitive aspects and non-cognitive aspects. The average score of Indonesian entrepreneurs' cognitive skills aged 15to 64 years old based on the IFLS-5 in Table 2 is still relatively low, which is 18.34 percent. This picture is consistent with Indonesia's PISA score $(395,3)$ in 2015 which is in a low position (ranked 62 out of 70 countries) and is still far below the average PISA score of OECD countries, which is 492. In 2014, the OECD also conducted an assessment of workforce skills in Indonesia aged 16 to 65 years old consisting of three aspects, namely literacy, numeracy, and problem-solving in technology. As a result, the level of literacy and numeracy of Indonesian workers is ranked the lowest of the 34 surveyed countries, while for problem-solving the rank is lower than the average OECD country (OECD, 2016).

For the aspect of non-cognitive skills based on the IFLS-5 in Table 2, it shows that the non-cognitive skills of entrepreneurs at the age of 15 to 64 years old in this analysis unit has an average of 55,36. This indicates that entrepreneurs in Indonesia have good character/personality. Character/personality that consists of: talkative, do the job perfectly, have new ideas/originality, spontaneous in expressing opinions, can deal with pressure well, forgiving, not worrying too much, imaginative, tend not to be lazy, artistic, 
caring, working efficiently, being able to socialize, not be rude, and not easily nervous is needed by entrepreneurs in running their businesses. Figure 2 shows the relationship between cognitive and non-cognitive skills to profit earned by entrepreneurs. Cognitive and non-cognitive skills show a positive relationship with the profits obtained. The profit gained by the entrepreneur will increase along with the increase in cognitive skills and non-cognitive skills.

Cognitive Score

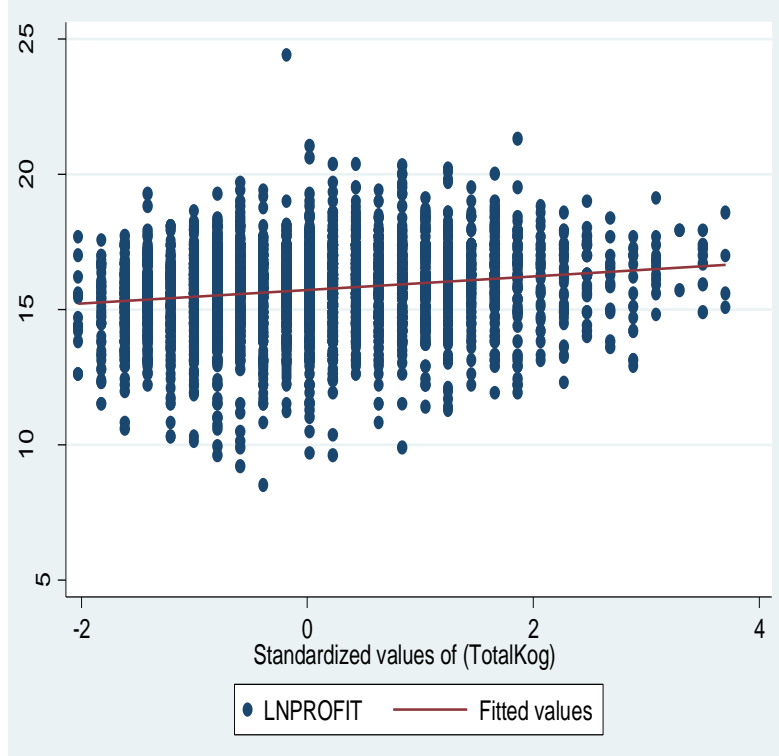

Non-cognitive Score

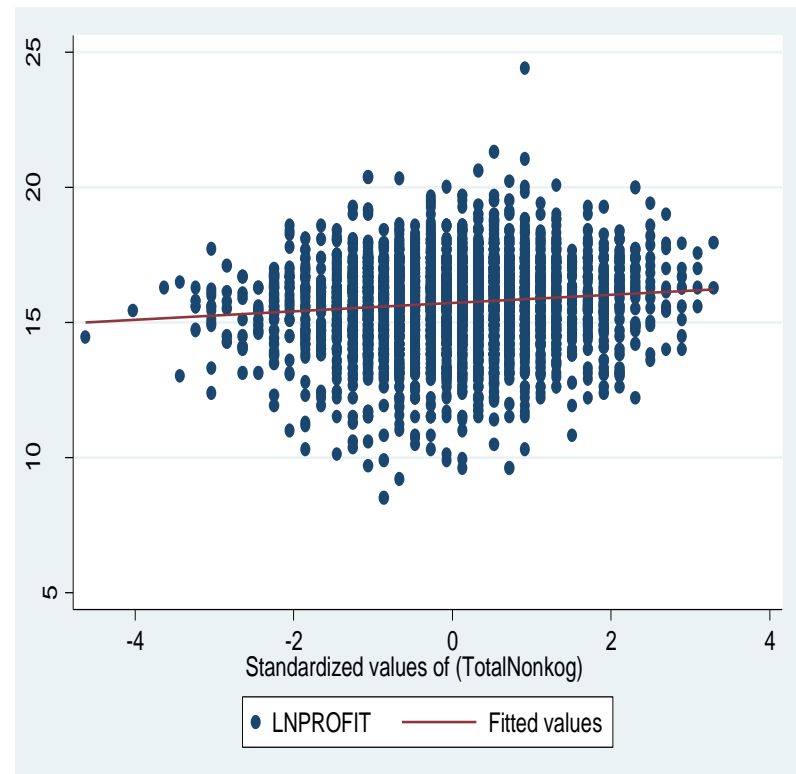

Source: IFLS-5, processed by the author

Figure 2. Profit Earned by Entrepreneurs Based on Cognitive and Non-cognitive Skills

Technological advances that are illustrated through the use of the internet also appear to have a relationship with the profits derived by entrepreneurs. Table 3 shows that entrepreneurs who use the internet tend to have high profits with the amount of 63,96 percent while entrepreneurs who do not use the internet tend to have low profits $(53,20$ percent). This shows that the use of technology such as the use of the internet will have a good impact on users, including on entrepreneurship. The use of the internet turned out to be not only for leisure but also can expand the reach of marketing or overcome the problem of barriers of space and time in business.

Table 3. Percentage of Profits Earned by Entrepreneurs Based on Internet Use

\begin{tabular}{|c|c|c|c|}
\hline \multirow[b]{2}{*}{ Internet Use } & \multicolumn{2}{|c|}{ Profits } & \multirow[b]{2}{*}{ Total } \\
\hline & $\begin{array}{c}\text { Low } \\
\text { (Below Average) }\end{array}$ & $\begin{array}{c}\text { High } \\
\text { (Above Average) }\end{array}$ & \\
\hline No & 53,20 & 46,80 & 100 \\
\hline Yes & 36,04 & 63,96 & 100 \\
\hline
\end{tabular}

The results of OLS (Ordinary Least Square) regression analysis are listed in Table 4. Before conducting an analysis with OLS (Ordinary Least Square) regression multicollinearity 
and heteroscedasticity tests were performed. The multicollinearity test results showed an average $V I F$ value of 1,19 and the VIF of each variable below ten. So, it can be concluded that there was no multicollinearity in the data of this study. Next, a heteroscedasticity test is performed based on a scatter plot between fitted values and residuals. The results show a random pattern meaning the assumption does not occur heteroscedasticity is met so that the OLS test can be performed. In addition, the analysis also does the Global Test to see independent variables that can be used together to form the model. Based on the results of the Global Test, the value is significant ( $p$-value $<0,05$ percent), meaning that the addition of the independent variable can have a significant effect on the model. Furthermore, a partial test of each variable is also performed and according to the results of the partial test conducted it is also significant ( $p$-value $<0,01$ percent, $p$-value $<0,05$ percent, or $p$-value $<0,1$ percent). Thus, the results can be interpreted that all independent variables have an influence on the dependent variable.

Table 4. Ordinary Least Square (OLS) Regression Results

\begin{tabular}{|c|c|c|}
\hline Variables & Coefficient & Significance \\
\hline Cognitive Skills & 0,125 & 0,000 \\
\hline Non-cognitive Skills & 0,036 & 0,091 \\
\hline $\begin{array}{l}\text { Internet Use } \\
\text { Yes } \\
\text { No (reference) }\end{array}$ & 0,159 & 0,014 \\
\hline Age & 0,090 & 0,008 \\
\hline $\begin{array}{l}\text { Sex } \\
\text { Male } \\
\quad \text { Female (reference) } \\
\end{array}$ & 0,817 & 0,000 \\
\hline $\begin{array}{l}\text { Education } \\
\text { High (D1-S3) } \\
\text { Middle (SMA/SMK) } \\
\text { Low ( } \leq \text { SMP) (reference) }\end{array}$ & $\begin{array}{l}0,745 \\
0,249\end{array}$ & $\begin{array}{l}0,000 \\
0,000\end{array}$ \\
\hline $\begin{array}{l}\text { Region } \\
\text { Urban } \\
\text { Rural (reference) }\end{array}$ & 0,280 & 0,000 \\
\hline $\begin{array}{l}\text { Konstanta } \\
\mathrm{R}^{2}\end{array}$ & 14,877 & 0,000 \\
\hline
\end{tabular}

Table 4 shows that cognitive skills have a significant and positive effect on the profits derived by entrepreneurs. The higher the cognitive skills of the entrepreneur will higher the profit obtained. Each increase in cognitive skills scores will increase the profit gained by entrepreneurs by 12,5 percent. These results are consistent with previous research (Hartog et al., 2010; Aldén et al., 2017) which states that high cognitive skills possessed by an entrepreneur can encourage the entrepreneur to manage and run his business optimally so that the profit obtained will be even greater. In addition, the cognitive skills of an entrepreneur will affect the entrepreneur in every decision making and action in running his business so that it will ultimately affect the success of the entrepreneur.

Furthermore, high non-cognitive skills variables such as talkative, do the job perfectly, have new ideas/originality, spontaneous in expressing opinions, can handle pressure well, forgiving, not worrying too much, imaginative, tend not to be lazy, artistic, caring, working efficiently, can be sociable, not rude, and not easily nervous will affect the 
profits derived by entrepreneurs. The OLS regression results in Table 4 show that each increase in one unit of non-cognitive skills owned by an entrepreneur will increase profits by 3,6 percent. The results of this study indicate that the skills of entrepreneurs both cognitive and non-cognitive skills have an influence on profits obtained even though the influence of cognitive skills is higher than the influence of non-cognitive skills.

The results of the inferential analysis in Table 4 also show that the internet has a positive and significant effect on entrepreneurs' profits. Entrepreneurs who normally use the internet will increase profits by 15,9 percent compared to entrepreneurs who do not use the internet. Internet access can be done on various media such as cellular phones, tablets, computers, or laptops. These results are consistent with the initial assumption that internet technology will facilitate entrepreneurs in carrying out their work. The increase in digital-based activities via the internet can also lead to opportunities for the emergence of businesses that do not require special places, such as online sales so that they do not have to have a special place or shop physically but the existence of these stores can be diverted at home. Internet use can also reduce individual work hours because it can make work completed more quickly.

The results of this inferential analysis also show that demographic factors such as age, gender, education level, and the area of residence of the entrepreneur have a significant effect on the profits they obtain. When the age of an entrepreneur increases one year, the profit earned by the entrepreneur will increase by around 9 percent. This is alleged with the increasing age of entrepreneurship, the experience possessed also increases so that he has more leverage in running the business.

The gender variable shows that male entrepreneurs get higher profits than women entrepreneurs. The profit gained by male entrepreneurs is 81,7 percent higher than that of female entrepreneurs. This is thought to be a result of gender discrimination in the labor market such as the opportunity to obtain capital and the division of time between work and household. In addition, differences in the characteristics of men and women such as courage in making decisions, emotional stability, and practical mindset can cause the profits derived by male and female entrepreneurs to be different.

Furthermore, the analysis also shows that entrepreneurs' profits are influenced by the level of education. Entrepreneurs with high education and middle education will get higher profits (74,5 percent and 24,9 percent respectively) compared to entrepreneurs with low education. These results indicate that education influences entrepreneurs when conducting their business activities because the knowledge obtained will greatly help entrepreneurs in managing their business. The knowledge gained from this education is general knowledge as well as specific knowledge about entrepreneurship.

The last, residence variable shows that entrepreneurs who live in urban areas will generate profits that are 28 percent higher than entrepreneurs who live in rural areas. This is thought to be caused by different technologies and environments between rural and urban areas. The development of technology and environment which are generally faster developing in urban areas will encourage entrepreneurs who live in urban areas to have higher profits. 


\section{CONCLUSION}

The results of this study indicate that cognitive skills, non-cognitive skills, and internet use have a significant effect on the profits derived by entrepreneurs. In addition, entrepreneurs who get older, of a male sex, have a higher education, and live in urban areas will increase entrepreneurs' success as measured by the profits obtained.

Some of the policy implications of this research are that policies on the education system and the labor market should begin to consider developing cognitive and noncognitive skills to improve outcomes in the labor market. It is especially on entrepreneurs because so far, the education system and labor market in Indonesia have not paid too much attention to non-cognitive skills. Policy in the education sector should begin to improve curriculum and learning methods on entrepreneurship intensively starting from education in kindergarten, primary, secondary, and high school in order to develop academic skills, general skills, technical skills, and personality. It is because as a child, cognitive and non-cognitive skills will develop optimally.

In addition, the development of skills can be done properly through job training and internships when starting to enter the work period. The government should also begin to encourage entrepreneurs to take advantage of advances in information technology not only in carrying out daily activities such as communication or outreach but can be able to use it in carrying out their work so that the development of entrepreneurs becomes better.

There are some weaknesses in this study. Firstly the data presented is only a crosssection of data at one point in time because the question of non-cognitive skills was only available in 2014 so that no other data can be used as a comparison. Secondly, there are entrepreneurs who do not respond to cognitive and non-cognitive skills. This resulted in some entrepreneurs not being included in the unit of analysis.

\section{REFERENCES}

Adhitya, D., Mulyaningsih, T., \& Samudro, B. R. (2019). The Role of Cognitive and Non-Cognitive Skills on Labour Market Outcomes in Indonesia. Jurnal Ekonomi Malaysia 5, 53(1), 3-16. http://dx.doi.org/10.17576/JEM-2019-5301-1.

Adioetomo, \& Pardede. (2018). Memetik Bonus Demografi: Membangun Manusia Sejak Dini. Depok: Raja Grafindo Persada.

Aldén, L., Hammarstedt, M., \& Neuman, E. (2017). All About Balance? A Test of the Jack-of-All-Trades Theory Using Military Enlistment Data. Labour Economics, 49(October 2015), 1-13. https://doi.org/10.1016/j.labeco.2017.09.001.

Anderson, L. W., \& Krathwohl, D. R. (2001). Taxonomy for Learning, Teaching, and Assesing: A Revision of Bloom's Taxonomy of Educatioanl Objectives. Addison Wesley Longman, Inc.

Bappenas. (2014). Rencana Pembangunan Jangka Menengah Nasional 2015-2019, Buku 1 Agenda Pembangunan Nasional. Jakarta: Bappenas.

Bloom, B. (1956). Taxonomy of Educational Objectives. The Classification of Educational Goals.Handbook 1 Cognitive Domain. Longmans, Green and Co. 
BPS. (2019). Penduduk 15 Tahun Ke Atas Menurut Status Pekerjaan Utama 1986 - 2019. https://www.bps.go.id/statictable/2009/04/16/971/penduduk-15-tahun-ke-atasmenurut-status-pekerjaan-utama-1986---2019.html.

Calderon, G., Iacovone, L., \& Juarez, L. (2016). Opportunity Versus Necessity: Understanding the Heterogeneity of Female Micro-Entrepreneurs. World Bank Economic Review, 30, 1-11. https://doi.org/10.1093/wber/lhw010.

Cobb-clark, D., \& Schurer, S. (2011). The Stability of Big-Five Personality Traits The Stability of Big-Five Personality Traits. IZA Discussion Paper, 5943.

Cubel, M., Nuevo-chiquero, A., Sanchez-pages, S., \& Vidal-fernandez, M. (2016). Do Personality Traits Affect Productivity? Evidence from The Laboratory. The Economic Journal, 126(2001), 654-681. https://doi.org/10.1111/ecoj.12373.

Das, K., Tamhane, T., Vatterott, B., Wibowo, P., \& Wintels, S. (2018). The Digital Archipelago: How Online Commerce is Driving Indonesia's Economic Development (Issue August). Jakarta: McKinsey \& Company.

Djankov, S., Miguel, E., Qian, Y., Roland, G., \& Zhuravskaya, E. (2005). Who Are Russia's Entrepreneurs? Journal of the European Economic Association, 3(May 2005), 587-597. https://doi.org/10.1162/jeea.2005.3.2-3.587.

Georgellis, Y., \& Wall, H. J. (2004). Gender Differences in Self-Employment. International Review of Applied Economics Taylor \& Francis Journals, 19(3), 321-342. http://research.stlouisfed.org/wp/1999/1999-008.pdf.

Halab1, C. E., \& Lussier, R. N. (2014). A Model for Predicting Small Firm Performance Increasing the Probability of Entrepreneurial Success in Chile. Journal of Small Business and Enterprise Development, 21(1), 4-25. https://doi.org/10.1108/JSBED-10-20130141.

Hartog, J., Praag, M. Van, \& Sluis, J. Van Der. (2010). If You Are So Smart, Why Aren't You an Entrepreneur? Returns to Cognitive and Social Ability: Entrepreneurs Versus Employees. Journal of Economics \& Management Strategy, 19(4), 947-989. https://econpapers.repec.org/RePEc:iza:izadps:dp3648.

Heckman, J. J., \& Kautz, T. (2012). Hard Evidence on Soft Skills. Labour Economics, 19(4), 451-464. https://doi.org/10.1016/j.labeco.2012.05.014.

Ilegbinosa, I. A., Moses, O. L., \& Praise, U. I. (2014). Population and its Impact on Level of Unemployment in Least Developed Countries: An Appraisal of the Nigerian Economy. Arts and Social Sciences Journal, 5(2). https://doi.org/10.4172/21516200.100081.

Kietzmann, J. H., Hermkens, K., Mccarthy, I. P., \& Silvestre, B. S. (2011). Social Media? Get Serious! Understanding the Functional Building Blocks of Social Media. Business Horizons, 54(3), 241-251. https://doi.org/10.1016/j.bushor.2011.01.005.

Kusumawardhani, N., Suryadarma, D., \& Tiberti, L. (2019). What Skills Lead to Entrepreneurial Success? Evidence from Non-Farm-Household Enterprises in Indonesia. Working Paper 2019-14. 
Li, X., He, X., \& Zhang, Y. (2019). The Impact of Social Media on the Business Performance of Small Firms in China. Information Technology for Development, O(0), 123. https://doi.org/10.1080/02681102.2019.1594661.

Lind, D. A., Marchal, W. G., \& Wathen, S. A. (2012). Business \& Economics. McGrawHill.

Marshall. (1890). Principles of Economics (8th ed.). London: Macmillan and Co.

Meisenberg, G. (2012). National IQ and Economic Outcomes. Personality and Individual Differences, 53(2), 103-107. https://doi.org/10.1016/j.paid.2011.06.022.

Mel, S. De, Mckenzie, D., \& Woodruff, C. (2008). Who Are the Microenterprise Owners? Evidence from Sri Lanka on Tokman v . de Soto. IZA DP, 3511.

Mueller \& Plug. (2004). Estimating the Effect of Estimating the Effect of Personality on Male-Female Earnings. IZA DP, 1254.

Nachrowi, N., \& Usman, H. (2002). Penggunaan Teknik Ekonometri (Edisi Revisi). Jakarta: PT.Raja Grafindo Persada.

OECD. (2016). Skills Matter: Further REsults from the Survey of Adult Skills. Paris: OECD Publishing. https://doi.org/10.1787/9789264258051-en.

Praag, V. (1997). Determinants of Ssuccesful Entrepreneurship Determinants of Successful Entrepreneurship. Amsterdam: UvA.

Rauch, A., \& Frese, M. (2007). Let's Put the Person Back Into Entrepreneurship Research: A Meta-Analysis on the Relationship Between Business Owners' Personality Traits, Business Creation, and Success. European Journal of Work and Organizational Psychology, 0643. https://doi.org/10.1080/13594320701595438.

Vial, V., \& Hanoteau, J. (2015). Returns to Micro-Entrepreneurship in an Emerging Economy: A Quantile Study of Entrepreneurial Indonesian Households' Welfare. World Development, 74, 142-157. https://doi.org/10.1016/j.worlddev.2015.04.008. 